\title{
German political discourse and its innovations
}

\section{O. Skliarenko}

SHEI «Pereiaslav-Khmelnytskyi state pedagogical Hryhorii Skovoroda university»

Corresponding author. E-mail: lesiaskliarenko82@gmail.com

Paper received 26.03.20; Accepted for publication 17.04.20.

\section{https://doi.org/10.31174/SEND-Ph2020-225VIII67-14}

\begin{abstract}
In addition to informative and correlated functions, the main characteristics of media discourse include suggestive and manipulative functions. Of particular interest is the consideration of the previous two in the relationship among linguistic and extralinguistic aspects. Most clearly, the creative nature of media discourse is manifested at the lexical level, which is associated with the emergence of new units, in particular, deonyms. Such new entities represent simultaneously means of linguistic economy, expressiveness and discredit of the concept. These provisions are illustrated on the examples of the political discourse of the German language.
\end{abstract}

Keywords: German language, vocabulary, terminology, deononym, media discourse.

Being informed nowadays plays a very important role in the context of the global information space and the unlimited possibilities of access to information. The most important functions of mass communication, especially in the sphere of political discourse, are, in our opinion, informative, correlative, suggestionistic and manipulative. The first two are of top priority importance. The media are designed to inform, explain and comment on events. At the same time, it cannot be denied that mass media have a persuasive force, especially when the recipients of information have not yet formed their opinion and do not have their own view on the events described.

In this case, journalists, as mediators of communication between professional politicians and citizens, have an enormous power of influence, with language being an important tool. In the opinion of E.S. Kubriakova, the influencing function of language is most clearly manifested in the media [1, p 61]. The use of certain linguistic means, for example, metaphors, in the texts of political subjects can contribute to the formation of the necessary image of the fact perception, and the frequency of their use is associated with the intensity of the development of events, which is quite clearly demonstrated nowadays by the example of the image of politic in the German media. Recently, quantitative and qualitative changes in the language of the media have become increasingly visible. Some researchers even believe that the media contribute to the barbarization of the language [1, p. 62]. Media discourse is undoubtedly creative, reflected primarily on a lexical level and directly linked to extra-linguistic factors. It is conditioned, firstly, by the diversity of the topics covered, and secondly, by the decentralization of information, which is a consequence of democratization and liberalization of society. All this leads to appearance of specific notions, language units in the language and may even influence terminological processes. Let us consider this statement on the example of the German language.

Politics and political journalism are separate professional fields and operate with their own terminology. This includes lexical units, which denote phenomena or concepts of a given subject area and reflect the specificity of an information text.

Structurally, they are diverse, they can be words of any part of speech, but mostly nouns, including complex nouns, which act in this role. Quite a lot of acronyms and borrowings are also found. Here are a few examples: die
Agenda, der Wahlkampf, die Hochrechnung, die Umfragewerte, der Meisterplan, der/die Abgeordnete, das AA, die GroKo, die K-Frage, der AfDler, die IAEA, die UNESCO, der Atomdeal, die Roadmap, der Global Player, die Pipeline, das Statement, antreten, designieren, kandidieren and the other. In defining the word "term", we rely on the definition presented in the dictionary of foreign words, because we consider it to be the most complete. [2].

According to the authors, we see "term" as a special word of a specific conceptual sphere of activity, which has a definition and is used in special conditions, and we consider it possible to consider the listed units as terms of political discourse in the media. It is not, however, an absolute statement that the term is inherently unambiguous and neutral. In the texts of political discourse in the media, one can find examples of multiplicity even within the same terminology field. So, the term "der Präsident" means both the President (der Bundespräsident), and the chairman (der Bundestagspräsident); two meanings also has a term "die Partei" - "party" (konservative Partei) and "side" (die Konfliktpartei, die Vertragspartei).

Some expressiveness of used language and political discourse is in general conditioned by its tasks - manipulation of public opinion and provision of certain emotional impact on the recipients of information. Own names occupy an important place in the media discourse. Media texts are full of anthroponcepts. Undoubtedly, political events are connected with the names of specific people, in our case, mainly politicians of any nationality: Angela Merkel, Barack Obama, Martin Schulz, Donald Tramp, Sigmar Gabriel, Frank-Walter Steinmeier, Theresa May and other. Analysis of their use suggests that anthroponyms have a dual function: firstly, they designate a media personality, secondly, they act as a kind of symbol, a sign of culture, implicitly expressing new information not related to a specific person, i.e. they become precedentsetting. (der Bendlerblock - the building of German Ministry of Defence, das Konrad-Adenauer-Haus - central office of the CDU party, das WillyBrandt-Haus - central office of the SDPU party and other). The peculiarity of the modern political discourse of the German media are the deonomastic names - own names, which have turned into the category of nominal names: (merkeln, adenauern, hartzen, entschrödern, Merkelianer, merkelisieren, Merkelsch, schäubleweise, Schulzomania and other). Their 
active use is connected with the suggestive function of mass communication, when the information process is presented as a theatrical action, dramatized, events and facts are given a shade of emotionality. Their active use is connected to the suggestive function of mass communication, when the information process is presented as a theatrical action, dramatized, events and facts are given a shade of emotionality.

All such names have seen negative connotation, and their appearance in the media discourse is quite justified, because, according to some researchers, the most important characteristics of this conceptosphere are evaluation and emotion. [1, p. 63]. Quite intensive deonimization of the names of politicians and statesmen has been manifesting itself in German lately. This is due to extralinguistic factors. Germany is shaken by political scandals, unseemly actions and misses of leaders of different levels are revealed. The situation is aggravated by the rapidly decreasing trust of citizens in the leading politicians and ruling parties, as well as the growing popularity of the right. All this is taking place on the eve of the next Bundestag election, so it is not surprising that the election battle is taking place in the conditions of fierce competition for votes. The stronger the emotional impact on them, the easier it will be to manipulate their opinion and direct it in the necessary direction.

Besides, resorting to creative titles, journalists can describe an event briefly, very expressively and in a different way, and give it an assessment. Thus, the dissatisfaction with the policy of the German Chancellor reflects various deonimas on behalf of Merkel, for example: "Die Weltpolitik wird noch nicht merkelisiert" [7, 09.06.2016]; "Es wird gemerkelt, bis es passt"[6, 13.03.2017]; "Die Merkelisierung Deutschlands" [9, 30.12.2018]; "Athen und Merkelsche Dialektik" [6, 19.08.2018].

The book by Urs Spreht "Wird Deutschland ausgemerkelt?" was published in Germany in 2015. In 2016 on German Unity Day, supporters of the Pegid movement held demonstrations in Dresden under the slogan of "Ausgemerkelt und ausgegauckt". Journalists divide politicians into supporters (Merkelianer) and opponents (Nicht-Merkelianer) of Merkel and her political course, describing their attitude towards her as "merkelfreundlich" and "merkelfeindlich". Online version of the famous Duden dictionary has an adjective "merkeltreu" included [3]. Even the sign of the Chancellor's usual gesture - the palms forming a rhombus - is a deonim "der Merkelizer". The number of deonyms on behalf of the current Chancellor of the Federal Republic of Germany is very large, so it is possible to systematize them and present them as a lexico-semantic microfield [12].

The exact opposite style of leadership is expressed by deonimas "merkeln" and "schrödern": In dieser Situation hat die Kanzlerin aufgehört zu merkeln. Sie wartet nicht mehr ab, zögert nicht mehr heraus, kalkuliert nicht mehr mit politischem Fingerhakeln und gesellschaftlichen Stimmungsentwicklungen. Merkel schrödert. Sie geht nach vorne, mutig, überzeugt und angriffslustig [9, 7.03.2018]. Interestingly, the second and fourth sentences in this paragraph explain the meaning of these neoplasms.

From linguistic point of view, these units are in opposition and represent antonyms. The appearance of former European Parliament President Martin Schulz on the
German political scene and his appointment as the head of the SPD and a Social Democrat candidate for Chancellor was immediately reflected in German: "Schulzomania und kein Ende" [10, 07.02.2018]; "Je Schulzer, desto AfD” [10, 5.02.2018]; "CDU stärkste Kraft, SPD profitiert von Schulz-Effekt" [7, 09.03.2018]. An interesting technique is used by journalists when they describe the actions of one politician as a deonime on behalf of another: "So entschrödert Schulz die SPD" [10, 21.02.2017]; "Niederlande vor der Wahl: Wilders trumpt auf" [10, 05.02.2017]; "EU-Kommissar vs Wallonen Kommunistenalarm! Wenn Oettinger adenauert" [10, 31.10.2017]; "Trotz der dummen Attacken einiger französischer Sozialisten gegen Angela Merkel scheint sich Präsident Hollande selbst zu merkelisieren" [8, 30.07.2018]. The above given examples clearly demonstrate the ironic and negative attitude to the actions and actions of the nameserver data carriers. In order to understand the meaning of such names, it is necessary to find out the history of their appearance in the language and know the events related to it.

According to the German linguist M. Wengeler, such designations not only serve as means of linguistic economy and expressiveness, but may even discredit the concepts expressed [12, pp 91-92]. It is here that, from our point of view, the influencing force of language is manifested and one of the distinctive features of mass media the pursuit of spectacularity - is confirmed. In some works devoted to the study of deonyms, different classifications are offered. For example deanthroponymic names can be subdivided into units with a predominant nominative-cognitive function and units with an expressiveevaluation function.

However, the author does not specify clear criteria by which this or that unit can be assigned to a certain group. The peculiarity of deonyms, in our opinion, is that they combine all the listed features. That's why they have expressive language means. Thus, the verb "hartzen" does not just mean "live on unemployment benefits", but also indicates the abuse of social opportunities provided by the state for unemployed citizens. Hence the second meaning of the verb, popular in the youth slang -“'idle, do nothing", as well as the meaning of other derivative units from the anthroponym Hartz [13]. In addition, it is quite possible that a unit that appeared in the language originally as a deononym will become a term. This is confirmed by examples from various types of discourse: pasteurisieren, Mozarttaler (culinary), Mauser, Junkers (military), röntgen, Dieselmotor, mendeln (scientific and technical), Bismarcksche Politik, salomonisches Urteil, Gorbi-Mania (historical), Luthertum, Thomismus, Thomist (religious). Such way has been taken, for example, by the term in political discourse "der Marxismus". The online version of the Duden dictionary states that the word appeared as jargon "aus dem marxistischen Jargon stammendes sprachliches oder stilistisches Element in gesprochenen oder geschriebenen Texten", and now is seen as a study - "von Marx und Engels begründete Lehre" [12].

The deononym "das Hartz" can pass the same way. This is the name of labour market reform in Germany, which is associated with the name of Peter Hartz. It provided some social benefits for unemployment, primarily for people who have been in the status of unemployed for 
more than a year and are not trying to change their situation. This is why the verb "hartzen" has the meaning "live on unemployment benefits". The word "RiesterRente/Riesterrente" also has a terminological character. Walter Riester, an economist and former Minister of Labor in G. Schröder's cabinet, proposed a private retirement benefit program for workers, which was negatively perceived in German society. "So funktioniert die RiesterRente" [8, 04.07.2017]. In the texts of the economic media, the unit is used exactly as a term and requires no explanation. Recently German sociologists have been actively using the term: "Schulz-Effekt": "vom Buchhändler zum Bundeskanzler? Manche Meinungsforscher sprechen vom Schulz-Effekt" [5, 27.02.2018].

And it is not clear who first used this unit - sociologists or journalists. In the Ukrainian media, it is interpreted as a "term". It is possible that under the influence of extra-linguistic factors, in case the Social Democrats will win and Schultz will be chosen as the new Chancellor, this unit will become a sociological term.

From our point of view, deononyms can be considered as politically engaged units. The appearance of deanthroponymic names is connected to actual events of social and political life in Germany. The processes of democratization, the priority of freedom of speech and the lack of censorship in modern society practically do not limit the scope of their use. Besides, own names in German are short and concise, which makes deonimization possible. In M. Wengler's opinion, this is what makes the name of its own into an onomic marker of a socially and politically significant phenomenon, and it is actively involved in the word educational processes of the standard German language [12, p. 80].

The use of deonyms in the media discourse helps to reduce the distance between the addressee and the addressee, makes the text of the information message more accessible. In creating their texts, journalists initially focus on the average recipient of information. In order to influence the mass consciousness, they reduce the intellectual level of their statements to simplicity and comprehensibility and thus ensure the interest in the text for the most diverse audience. An expressive language tool such as deonyms works equally well in oral speech, in discourse approaching space and in media discourse. A confirmation of this can be found on the website of the Academy of Sciences Berlin-Brandenburg [3]. It is both a dictionary and a corpora of texts in modern German. Even a brief analysis makes it possible to assert that the sphere of deonyms use is publicist texts (Zeitungskorpora) and blogs (Spezialkorpora). In addition, it is these expressive units that perform the socio-cultural functions of a media culture, ensuring the informativeness, accessibility, comprehensiveness and visibility of visual perception.

\section{LITERATURE}

1. Кубрякова Е.С. О разных подходах к изучению СМИ // 7. Faz.Net. URL : www.faz.net.de Язык средств массовой информации как объект междисциплинарного исследования: тез. докл. М.: Филол. фак. МГУ им. М.В. Ломоносова, 2001. С. 61-62. 4.

8. Focus. URL : www.focus.de

9. Rponline. URL : www.rp-online.de

10. Spiege. URL : www.spiegel.de

11. Süddeutsche. URL : www. sueddeutsche.de

2. Словник іншомовних слів [Е. ресурс]. Режим доступу : www.jnsm.com.ua/cgi-bin/u/books/sis.pl

3. Digitales Wörterbuch der deutschen Sprache. URL : www.dwds.de

4. Duden. URL : www.duden.de / woerterbuch

5. Euronews. URL : www.euronews.de

6. Tagesspiege. URL : www.tagesspiegel.de

12. Wengeler M. Schaubleweise, Schröderisierung und riestern. Formen und Funktionen von Ableitungen aus Personenamen im öffentlichen Sprachgebrauch // Komparatistik Online. Dusseldorf, Trier. 2010. S. 79-98

13. Why the German language has so many great words [E. pecypc]. Режим доступу : theconverstaion/why-the-germanlanguage-has-so-many-great-words-55554.

\section{REFERENCES}

1. Kubriakova E.S. About different approaches to the media study // The language of media as an object of intercultural research: theses. M.: Philological faculty M.V. Lomonosov

MSU, 2001. PP. 61-62. 4.

2. Dictionary of foreign words. URL : www.jnsm.com.ua/cgibin/u/books/sis.pl.. 